\title{
Tulane
}

\author{
Tulane Economics Working Paper Series
}

\section{Citizen "Trust" as an Explanation of State Education Funding to Local School Districts}

\author{
James Alm \\ Department of Economics \\ Tulane University \\ New Orleans, LA \\ jalm@tulane.edu
}

\author{
Robert D. Buschman \\ Fiscal Research Center \\ Andrew Young School of Policy \\ Studies \\ Georgia State University \\ Atlanta, GA \\ rbuschman1@gsu.edu
}

\author{
David L. Sjoquist \\ Economics Department \\ Georgia State University \\ Atlanta, GA \\ sjoquist@gsu.edu \\ Working Paper 1208 \\ July 2012
}

\begin{abstract}
Many previous studies have examined the level of state grants to local $\mathrm{K}-12$ school districts. However, these studies have not considered the role of citizen trust in state versus local governments as a factor. We hypothesize that the role of the state in funding education reflects citizen "trust" in the relative capabilities of governments. We measure "trust" directly via public opinion polls that capture citizen attitudes about the appropriate responsibilities of state versus local governments; we also measure "trust" indirectly, by the role of state government as revealed by its relative importance in overall service provision (net of $\mathrm{K}-12$ spending). We find that the state share of $\mathrm{K}-12$ education spending tends to be higher when there is greater citizen trust in state versus local governments.

Keywords: property tax, state and local finance, fiscal federalism, education, public opinion, intergovernmental transfers

JEL: H71, H75, H77
\end{abstract}




\title{
CITIZEN "TRUST" AS AN EXPLANATION OF STATE EDUCATION FUNDING TO LOCAL SCHOOL DISTRICTS*
}

\author{
James Alm \\ Robert D. Buschman \\ David L. Sjoquist
}

\begin{abstract}
$\underline{\text { ABSTRACT }}$
Many previous studies have examined the level of state grants to local K-12 school districts. However, these studies have not considered the role of citizen "trust" in state versus local governments as a factor. We hypothesize that the role of the state in funding education reflects citizen "trust" in the relative capabilities of governments. We measure "trust" directly via public opinion polls that capture citizen attitudes about the appropriate responsibilities of state versus local governments; we also measure "trust" indirectly, by the role of state government as revealed by its relative importance in overall service provision (net of K-12 spending). We find that the state share of K-12 education spending tends to be higher when there is greater citizen trust in state versus local governments.

* Tulane University; Georgia State University; and Georgia State University. An earlier version of this article was presented at the conference "States as Facilitators or Obstructionists of Local Governments" held at the DeVoe Moore Center and the LeRoy Collins Institute at Florida State University in February 2010. We are grateful to participants of the conference, three anonymous referees, and Carol Weissert for many helpful comments. Please address all correspondence to: James Alm, Department of Economics, Tulane University, 6823 St. Charles Avenue, 208 Tilton Hall, New Orleans, LA 70118 (phone 504862 8344; fax 504865 5869; email jalm@tulane.edu).
\end{abstract}


The appropriate role of state versus local governments in funding K-12 public education remains a major source of controversy. For nearly forty years this controversy has found its way into the courts, beginning in 1971 with Serrano v. Priest in California, and these cases have forced state governments to take an increased role in funding education. While the state share of funding for K-12 education has increased over time, there is wide variation in the percentage of funding for K-12 public education that is attributed to state government.

Figure 1 illustrates the trend in the state share at the national level, and shows a gradual increase in the state share, from 16.5 percent in 1919-1920 to a high of 53.6 percent in 20002001 before trending slightly down in the last several years. Table 1 and Figure 2 illustrate the variation of the state share across states. For example, in 2006 the state share ranged from 29.0 percent in Nevada to 99.0 percent in Hawaii (Table 1). Figure 2 is a scatter plot of state shares averaged over the school years ending 1992-1996 versus 2002-2006, and shows that for most states the state share decreased slightly over the period, while sixteen states had modest increases in the state share.

\section{Figure 1 about here}

Figure 2 about here

\section{Table 1 about here}

Although there is research that attempts to explain the overall level of fiscal decentralization across U.S. states, there are few articles that examine more specifically the level of decentralization as reflected in state support for education. In this article we explore determinants of the fiscal centralization of education funding, focusing especially on the role of 
citizen "trust" in the relative capabilities of state versus local governments as a determinant of state support for education. In particular, we examine interstate differences in the state share of state plus local education revenue, considering the effects of standard economic, demographic, and legal factors but focusing especially on the role of citizen "trust" in the state versus local governments. We measure "trust" directly via public opinion polls that capture citizen attitudes about the appropriate responsibilities of state versus local governments; we also measure "trust" indirectly, by the role of state government as revealed by its relative importance in overall service provision (net of K-12 spending). We hypothesize that the role of the state in funding education reflects the general voter attitude toward fiscal decentralization as measured by our various measures of citizen "trust". We explore these hypotheses using several empirical approaches. Consistent with our hypothesis, we find that the state share of K-12 education spending tends to be higher when there is greater citizen trust in state versus local governments and when state spending on non-education services is greater.

\section{THEORETICAL AND EMPIRICAL WORK ON THE DETERMINANTS OF \\ DECENTRALIZATION}

There are several literatures that are relevant here: theoretical work on factors that determine the appropriate degree of decentralization, empirical work on the determinants of decentralization in general, and empirical work on the determinants of education spending in particular. Each area is discussed.

\section{On the Theory of Decentralization $^{1}$}

\footnotetext{
${ }^{1}$ Epple and Nechyba (2004) provide a comprehensive discussion of issues associated with fiscal decentralization.
} 
Decisions regarding the centralization of education funding are a part of the broader issue of "optimal" fiscal decentralization. There are several different ways that one might model the choice of the degree of decentralization.

The most common approach starts with the premise that the choice of the level of decentralization is made to maximize social welfare. Drawing on the Oates (1972) model of optimal jurisdiction size, this approach recognizes that there are social benefits and costs from decentralization. The benefits of decentralization include greater information about citizen preferences at the local level and greater potential for differential provision of local public services to a population with a diversity of preferences. Costs include foregoing the possibility of economies of scale or imposing benefit spillovers on neighboring jurisdictions, both of which are better captured by centralized provision. The empirical research based on this approach implicitly assumes that decentralization reflects these benefits and cost, and thus the articles introduce variables reflective of how these benefits and costs differ across jurisdictions or countries; these articles are discussed in the next subsection.

A second approach focuses more on the "political economy" aspects of decentralization, and stems from the work of Borcherding and Deacon (1972) and Bergstrom and Goodman (1973). This approach assumes that the decision on decentralization is based, not on social welfare maximization, but on the preferences of the median voter.

This political economy framework can be expanded to consider other relevant institutional aspects. One strand recognizes the multi-tier aspect of governments, in which (say) state education revenue is determined by the state's median voter while the local revenue is modeled as a median voter decision given the structure of the state education grant program. For example, de Bartolome (1997) suggested that state grants for education can be seen as a form of 
redistribution. Assuming a foundation aid program, he created a median voter model in which separate decisions are made as to the level of student aid and the parameters of the foundation program. Given that median income is less than mean income, he showed that a political equilibrium is reached in which a more skewed distribution of income generates a larger share of state aid for education.

Related work by Hoxby (2001) explored how the structures of state education program and property taxation interact to affect the level of local education revenue; that is, once the state funding program is set, each local school district determines the local revenue within a median voter framework given the funding programs' effects on tax price and resources. Other political economy factors can also be introduced. Thomas (2000) developed a model based on Becker's (1983) model of lobbying by special interest groups. Although her real interest was in whether a more centralized school funding program will result in lower total spending on education, her model is also relevant to determining the level of centralization of school funding. Thomas assumed two local school districts, one wealthy and one poor, and an agent from each district who lobbies the state for the state share of revenue for education in order to achieve thedistrict's own interests. Total education grants are distributed based on a foundation program so that the poor district receives a larger per student grant. Whether the agent desires greater centralization depends on the progressivity of the state tax system: the more progressive the state tax system, the greater is the preference of the poor district for a more centralized school funding program.

An alternative political economy approach based on a budget-maximizing bureaucracy has been suggested by Panizza (1999), as an extension to two governmental levels of the Alesina and Spolaore (1997) framework. Panizza (1999) presented a stylized model in which there is a central government and local governments. He assumed that the central government has a utility 
function that depends on the size of central government's budget, that all individuals have the same income but differ in their tastes for public goods, and that the individuals are sorted over space so that utility from public goods falls uniformly the further the individual is from the center of the country. The central government acts first and determines the level of centralization by maximizing a utility function that depends on the level of its budget and the level of democracy (i.e., the degree to which the government's choice can differ from the preferred spending on public goods by the median voter). Given the level of centralization, citizens then vote on the amount of the public good and on the type of public good. The model predicts that the level of centralization is inversely related to country size, income per capita, tastes differentiation, and the level of democracy.

Joanis (2009) considered the case in which the central and local governments jointly provide a public good. He assumed that voters know the total level of the public good but have imperfect information as to the contribution of each of the two governments; he also assumed that the contributions from the two governments are not perfect substitutes in the production of the public good. Both governments maximize expected rent extraction under the constraint that the respective officials need to be reelected, where spending by one government affects the probability of its election as well as that of the other government. In equilibrium, each government's contribution to the public good equates its marginal benefit from reelection to the marginal cost of foregone rents, taking the other government's strategy as given. These results imply that decentralization should depend on the relative competencies of the two governments (i.e., the productivity of the two resources in producing the public good), the split of the tax base between the two governments, and the relative reelection uncertainties at each level, with greater 
uncertainty reducing the incentive to spend on the public good. Jametti and Joanis (2009) provide empirical support for the model.

Hatfield and Padro i Miquel (2008) also derived a positive theory of fiscal decentralization in which the level of decentralization between a central government and several local governments is the result of balancing the desire for redistribution with the need to avoid distortive taxes. The outcome is determined by citizen voters, and thus the model does not depend on a benevolent government as in Oates (1972) or on rent seeking as in Panizza (1999). They assumed two sources of revenue, a distortive capital tax and a neutral head tax. Since a relatively poor median voter prefers to shift tax burden to capital owners, public goods supplied by the central government will be financed by capital taxes, while locally provided public goods will be financed by head taxes because of competitive pressures. In deciding on the level of centralization, the median voter faces a trade-off between the benefits of more redistribution of capital rents but at a cost of a reduced capital supply. They showed that decentralization increases with redistribution efficiency, and is non-monotonically related to existing inequality (e.g., negatively related when inequality is low but positively related when inequality is high).

\section{On the Empirical Determinants of Decentralization}

Most of the empirical literature that explores the determinants of decentralization focuses on comparisons across countries, although there is some research that focuses on U.S. states. Oates (1972) was the first to investigatethe factors associated with the overall degree of fiscal centralization. He argued that there are three sources for differences across countries in the level of centralization: differences in the assignment of service responsibilities, differences in the composition of services provided, and differences in the degree to which services are provided 
by the private sector. To explain the differences in the level of decentralization, he identified three factors from his own theory that he thought would be associated with differences in the optimal centralization across countries. First, if there are economies of scale, then smaller countries (measured by population or area) should be more centralized. Second, if there is substantial diversity of demands for public services, then there should be more decentralization. Third, given that Wagner's Law suggests that public expenditure increase as income increases, increases in income could lead to a change in the mix of public services and thus to changes in centralization.

Oates (1972) explored these hypotheses using a cross-section of fifty-eight countries. He found that centralization falls as population or area increases (a reflection of economies of scale), and also as income increases (a reflection of Wagner's Law). As for diversity of preferences, he used three dummy variables to measure diversity: linguistic, racial, and religious diversity. None of these coefficients was statistically significant. He also used an alternative measure of diversity that reflects the level of sectionalism (e.g., the extent to which people in geographical subareas identify with the subarea), and found that a higher level of sectionalism is associated with more fiscal decentralization. Oates (1972) did not include any political factors.

There have been many subsequent articles that have explored the determinants of decentralization across countries. These studies typically have relied upon some subset of a basic set of variables that include income per capita, size (usually measured by population), density, urbanization, income inequality, ethnic heterogeneity, and grants to sub-national governments. In a survey of this work, Letelier (2005) concluded that these articles are largely inconclusive. 
Panizza (1999) tested the hypotheses that stem from his theory using a large crosssectional dataset of 60 countries for three separate years. His findings were supportive of the predictions of this theoretical model, namely that the level of centralization is inversely related to country size, income per capita, taste differentiation, and the level of democracy. These results are also consistent with Oates' (1972) hypotheses.

Giertz (1976) further extended Oates' (1972) analysis by considering the differences in decentralization across U.S. states. He used alternative measures of decentralization, and included variables that reflect economies of scale as well as several measures of demand diversity, including density range, urban range, income range, the Gini coefficient of income inequality, an index of political conservatism, and the political composition of the lower house of the state legislature. Giertz (1976) found that the independent variables were generally of the expected sign and statistically significant.

Wallis and Oates (1988) also explored factors associated with centralization across U.S. states, using the same basic framework that decentralization should be explained by factors associated with economies of scale, composition of services, and diversity of demand. They posited seven hypotheses that match the basic hypotheses in Oates (1972) and Giertz (1976). They expected centralization to be negatively related to land area, population, the percent urban, the degree of income inequality, and the diversity of the population; they also expected centralization to be positively related to per capita income on the assumption that greater income generates more "taste" for redistribution, which can most effectively be undertaken at a more centralized level. Wallis and Oates (1988) estimated equations using the state shares of expenditures and of revenues as alternative dependent variables with a dataset comprising a panel of forty-eight states for nine different years reflecting one year for each decade between 
1902 and 1982. They estimated an equation using the full panel (in which they included time and state dummies), and separate OLS regressions for each year. Their empirical results were somewhat mixed. For example, they found that land area, per capita income, and race were not statistically significant in the regression using the full panel, while the magnitudes and significance of the coefficients varied across the OLS-by-year regressions. In fact, their OLS regressions were weaker statistically than the panel regressions, suggesting some kind of secular trend in the level of centralization that is better captured in the panel dataset. Like Oates (1972), Wallis and Oates (1987) did not include any political factors.

The role of "trust" has been largely ignored as a determinant of decentralization, although there are some exceptions. Dincer (2010) considered the relationship between decentralization and "trust" in people (as distinct from "trust" in government). Using an index of trust developed elsewhere, he considered whether fiscal decentralization in U.S. states increases trust in people, and he found a positive relationship between the level of fiscal decentralization and the level of trust in people. ${ }^{2}$ However, he did not examine citizen "trust" in government, including the potential role of citizen "trust" in government as a determinant of decentralization. Also, Schneider, Jacoby, and Lewis (2011) examined the relationship between public opinion and the assignments of responsibilities between national, state, and local governments, with opinion data from a national sample of 1000 American adults from the 2006 Cooperative Congressional Election Study. They found that citizen opinions about government policy responsibilities in fact correspond closely to actual governmental program efforts of the different levels of government; that is, citizen preferences as reflected in opinion polls tend to be consistent with policy

\footnotetext{
${ }^{2}$ Note that Strumpf and Obersholzer-Gee (2002) found that states with more heterogeneous preferences are more likely to decentralize liquor control, where heterogeneity is measured by differences in education and religious affiliation.
} 
outcomes. However, they did not consider whether citizen attitudes are in fact a determinant of these policy outcomes. ${ }^{3}$

\section{On the Empirical Determinants of Education Spending}

There is a vast literature that has explored the determinants of the level of education funding. Many of these articles have considered the effects of school funding court cases (Evans, Murray, and Schwab 1997; Downes and Shah 2006) or have focused on the incentive effects of school funding formulae (Hoxby 2001). Some of this work was also designed to test directly the implications of the theoretical models discussed earlier. For example, an implication of the theoretical model of de Bartolome (1997) is that an observed increase in state education revenue is due to increased income inequality. de Bartolome (1997) tested his model using state panel data for 1970, 1980, and 1990. In his regressions explaining the level of state education revenue, he found that the coefficient on median income was negative, while the coefficient on mean income was positive, as predicted by his theoretical model. He also included a dummy for a court ordered reform of the state's education funding formula, which had the expected positive effect on state aid.

Similarly, Thomas (2000) used her theoretical model to examine empirically whether an increased state share leads to a reduction in total spending on education, using U.S. state-level data for 1990. Of relevance here, since the state share depends on the level of local funding, she also estimated an equation to explain the state share. For this equation, Thomas (2000) found significant coefficients for the poverty rate (a positive sign), tax regressivity (a negative sign), the number of students per district (a negative sign), and losing a court case (a positive sign).

\footnotetext{
${ }^{3}$ See also Wlezien and Soroka (2011), who found some evidence that Canadian citizen preferences for federal spending are affected by changes in federal and provincial government spending.
} 
Focusing specifically on the centralization of education funding, Bahl, Sjoquist, and Williams (1990) addressed the effects of school reform on centralization. They ran simple regressions using panel data with time and state fixed effects in which the dependent variable was either the state share of education revenue or the share of property tax revenue in total education revenue; the independent variables were dummy variables reflecting whether the state had a court-ordered reform of its education funding program or a legislative-initiated reform. They found that the coefficients on both reform variables were positive and significant for the state share equation, and negative and significant for the property tax share equation.

\section{EMPIRICAL MODEL AND DATA}

We focus here on the determinants of the fiscal centralization of education funding, in particular interstate differences in the state share of state plus local education revenue, and we build on the existing empirical literature on the state share of education funding. Insights provided by the theoretical model of Joanis (2009) are especially relevant since K-12 education is funded by two levels of government, and our empirical formulation is broadly similar to those articles that follow in the Oates (1972) tradition, with the important addition that we also include variables that reflect the preferences of citizens regarding state versus local funding.

Specifically, we assume that voters have preferences over the share of education funding that comes from the state. Such preferences might be based on one's beliefs about the role of state versus local governments, their faith or trust in different levels of government, or their belief that the state (or the local) government is better able to provide more equitable or adequate funding for education. For simplicity, we refer to the sum of these sources of preferences as "trust" in state government versus local government. 
There is a substantial literature that explores the relationship between public opinion and public policies. ${ }^{4}$ However, as argued by Schneider, Jacoby, and Lewis (2011, very little is known about the relationship between public opinion and the level of decentralization. As noted earlier, they explored the empirical relationship between public opinion regarding which level of government should take the lead on several policy areas, and they found that citizen preferences tend to be consistent with policy assignments. We focus instead on the state versus local role in funding K-12 education, in an attempt to determine whether public opinion seems to be a driving factor in these assignments.

There are several advantages to exploring fiscal centralization using K-12 education funding as our focus. First, because education is always produced at the local level, there are no differences across states in the mix of governmental levels in the provision of education, so that we can focus entirely on the sources of funding. Second, education is an essential public service, accounting for 41 percent of total direct expenditures of state and local governments.

Here we examine the state share of total state and local (SL) spending on K-12 education (excluding federal funds to SL governments for education spending) for forty-eight states (excluding Hawaii and Alaska). We measure total spending by total revenues rather than by SL actual expenditures because it is not possible to separate expenditures by funding source. These data were obtained from the Digest of Education Statistics published by the National Center for Education Statistics (NCES) and available at http://nces.ed.gov/programs/digest/. We exclude Hawaii because it is a state-funded education system, and we exclude Alaska because of its heavy reliance on a unique revenue source (oil).

\footnotetext{
${ }^{4}$ For example, see Dahl (1989), Cantril and Cantril (1999), Alvarez and Brehm (2002), Erikson, MacKuen, and Stimson (2004), and Stimson (2004).
} 
We estimate cross-section and panel regressions with data from various school years ending 1990-2006, including explanatory variables that have often been used in empirical studies of decentralization and in studies that explore state funding for K-12 education. These control variables reflect economic, demographic, and legal characteristics of the states. Of most interest here, we also employ several measures that capture citizen "trust" in state versus local governments, including direct and indirect measures that are reflective of different aspects of voter preferences toward state versus local government.

We hypothesize that a state's citizens have preferences regarding the share of education funding contributed by the state that is independent of the level of total spending on education in the state. In particular, we hypothesize that if citizens have greater "trust" in the state (or the centralized) government as opposed to local government, then the state share of funding for K-12 education should be greater. Again, by "trust" we mean the various beliefs or other factors that lead an individual to prefer that one level of government fund K-12 education rather than another level of government. Indeed, the basic economic rationale for decentralization is that a government that is "closer to the people" will make decisions that are more in line with the preferences of those citizens than a government that is distant. However, this requires in turn that citizens have confidence - or "trust" - that the government will actually make and implement appropriate decisions. When citizens have greater confidence in a more distant state government than in a closer local government, we hypothesize that state involvement in, and state control of, local education spending will be greater. We think it likely that such greater state control will be reflected in a larger state share of funding for K-12 education. 
We measure this "trust" in different ways, using both direct and indirect measures of trust. Our direct measures of "trust" are based on two different opinion poll results. ${ }^{5}$ First, we rely on an opinion poll conducted in 1996 by the American National Election Studies (ANES). There were two particularly germane questions, one asking the respondent in which level of government he or she had the most faith and the other asking in which level of government he or she had the least faith. ${ }^{6}$ We use the "Most Faith In" question results. Because of the small sample size, it is not feasible to have reliable values of the variable for all states, and we restrict our sample to states with at least twenty-five responses. Because this variable is not available for multiple years, we report a series of cross-section regressions.

Second, we combine several surveys conducted by the Advisory Commission on Intergovernmental Relations (ACIR). Each of these surveys asked the following question: "From which government, federal, state, or local, do you get the least for your money?" We have the results for surveys conducted in 1989, 1990, 1992, and 1994, which when taken together give us thirty-six states with twenty-five or more responses in total from the four

\footnotetext{
${ }^{5}$ Note that all of the direct measures capture mainly individual attitudes toward local governments in general, and not to local school districts in particular. The direct measures on local governments seem likely to be correlated to citizen attitudes toward local school districts, but perhaps with some imprecision. Unfortunately, survey responses on attitudes toward local school districts are not available. We are grateful to an anonymous referee for helping us to clarify our thinking about these survey variables.

${ }^{6}$ The exact wording of the "Most Faith In" question is:

VCF0630 Government Level in which R Has Most Faith QUESTION:

We find that people differ in how much faith and confidence they havein various levels of government in this country.In your case, do you have more faith and confidence in the nationalgovernment, the government of this state, or in the local governmentaround here?

VALID CODES:

1. National government

2. State government

3. Local government

9. DK; none; all; other; depends; refuses to choose; combination of two
} 
surveys. We considered using the surveys to construct a four-period panel, but found too few states with sufficient observations in all years to provide an adequate panel data set. ${ }^{7}$

Clearly, these are not ideal measures of public opinion concerning the relative role of state and local government in funding K-12 education. Ideally, we would like large number of observations in each state and several questions that relate directly to opinions on K-12 funding, all over multiple years. However, these public opinion polls are the only ones we could identify, and they have limited numbers of observations by state and by year.

We also include two indirect measures of citizen trust. Unlike the survey measures, these indirect measures are available for all years of our panel. For a first measure, we use per capita state spending net of K-12 education, as a measure of non-educational state service provision. We expect that voter preferences for a higher level of state services in general would be associated with greater reliance on specific state funding for K-12 education; that is, larger state government in areas other than education may imply a larger state government role in education.

As a second measure, we use state spending net of K-12 education as a share of total state plus local spending net of K-12 education. The state's share of non-education spending demonstrates directly the voter preferences for centralization or decentralization in those government service areas, independent of the level of spending. If these preferences extend to education as well, then we would expect a positive coefficient. On the other hand, a zero coefficient would suggest that preferences for centralization do not necessarily generalize across governmental functions, and a negative coefficient might suggest a trade-off where greater

\footnotetext{
${ }^{7}$ Specifically, we found that too few states had sufficient observations in all four ACIR surveys to make for a workable panel data set; that is, only ten states had twenty or more respondents in all years, so that a panel of states with this ACIR survey question was not feasible. Even so, we estimated this specification, but we did not get meaningful results.
} 
reliance on the state in one area leads to a smaller reliance on state government in other areas, perhaps due to a crowding out effect as fewer state resources are available in these other areas.

These indirect measures are, at least in part, potential reflections of citizens' relative "trust" in state versus local government. To the extent that our basic hypothesis is correct, it follows that the level of centralization of other expenditures should be a reflection of relative "trust" in state versus local government.

It is, of course, possible that opinion regarding K-12 funding centralization is driven by the level of centralization. While this is a potential issue, we do not believe that it is in our case because it seems unlikely that the state share of funding for the specific category of K-12 funding could cause citizens to form very general attitudes regarding their overall level of "trust" in state and local governments.

Among the economic variables, we first include per capita income, a typical variable used in studies of both decentralization and spending determinants. It could be argued that centralization may simply be a superior good, and thus a positive coefficient on per capita income would be found. Apart from the direct fiscal consequences for them personally, some citizens may have preferences for more equity in the available resources to local school districts, perhaps because of concern for possible externalities that arise from students getting a good education or because of the desire for equity; again, a positive coefficient on income would be expected. Alternatively, the effect of income could reflect citizens' preferences for state revenue sources. In most states, local revenue is raised mainly by the property tax and citizens with higher incomes may prefer the use of non-property taxes. A negative coefficient on income, on the other hand, may reflect citizens' preferences at higher income levels for more local versus state control. Studies of fiscal centralization generally find mixed effects of per capita income. 
Our second economic variable is housing prices, which may affect the state share of funding in as much as they proxy for the level of local resources. Local education revenue is generated largely by property taxes, and it is commonly thought that raising property tax rates is politically difficult. However, if the property tax base is increasing, then local school districts can generate additional revenue without changing property tax rates. (Of course, if there is an institutional constraint on allowable increases in the property tax levy, such as a tax rate or assessment limitation, then increases in the property tax base may not translate into additional revenue.) The Federal Housing Finance Agency produces a quarterly home price index for each state. We use these data to construct our proxy measures of the valuation change in the property tax base, and we hypothesize that appreciating home prices will increase local education funding, thus reducing the state share. Also related to the property tax base and voter preferences, we control for the fraction of owner-occupied housing, expecting that greater homeownership would increase resistance to the property tax and thus increase the state share of funding.

It is possible that centralization of K-12 funding and attitudes toward local government are driven by attitudes toward the property tax. For example, if citizens are strongly opposed to the property tax, then it is likely that they will prefer that the state fund a larger share of K-12 education. We argue that, if citizens have negative views of the property tax, then those views will be reflected in the adoption of property tax limitations. To control for the presence of such constraints on property tax revenues, we construct a dummy variable that is equal to one where Hoyt, Coomes, and Biehl (2008) indicate there are tax rate, assessment, or levy restrictions applicable to local school districts, and zero otherwise. We expect the presence of these restrictions on school districts to be associated with a smaller local and a greater state share of funding, ceteris paribus. 
As an indicator of budgetary pressures on the state level, we divide state year-end fiscal balances (general fund and "rainy-day" fund balances) by total state expenditures, and include this ratio as an additional control. Alm, Buschman, and Sjoquist (2007) found that higher relative fiscal balances are associated with significantly higher state funding per student, with no significant effect on local funding, suggesting a positive effect on the state share.

We also test several commonly used demographic variables: adult educational attainment (percent of the twenty-five and older population with a BA or more), the share of population of school-age (five to seventeen years of age), and the share of population over age sixty-five. It is not clear how these factors might affect preferences for state versus local funding.

Further, we include the average number of students per local school district. Other than in heavily rural states where lower population density limits the numbers of students a district can serve practically, a larger number of districts for a given number of students (i.e. fewer students per district) seems a fairly direct indicator of a preference for decentralization via more localized control. Consequently, we expect that the average district size (in students) is positively related to the state share of education funding. In addition, we use the number of students (in natural log form) to control for overall size of the state school system. Oates (1972) argued that larger countries should be more decentralized due to economies of scale, but this argument seems not to apply when considering the state share of funding for a locally provided service. Another hypothesis is that larger state systems are likely to see greater inequality across districts and thus require greater centralization for the purpose of redistribution

Oates (1972) argued that the greater the heterogeneity of preferences the greater is the degree of fiscal decentralization. To reflect the heterogeneity of preferences, studies of fiscal centralization have relied upon measures of the racial and ethnic makeup of the population. We 
include a measure of racial homogeneity, calculated by squaring the difference between the white population and 0.5. For example, a 100 percent white (or 100 percent non-white) population would result in a score of 0.25 , while a 50 percent white population would result in a score of zero. We also include measures of citizen and government ideology, in order to represent political preferences. These variables are based upon indicators introduced by Berry et al. (1998), and they measure ideology on a 100-point scale from "conservative" to "liberal", based in part on ideological ratings of incumbent office holders and challengers and also on voting patterns. We believe these variables are more refined measures of political preference than other commonly used variables such as those based on (say) the party in power, since a party label does not represent an identical political ideology across states.

As for legal variables, many states have implemented state lotteries as a means of raising non-tax revenues that are often earmarked for education. Using information in Evans and Zhang (2007) and from the website of the North American Association of State and Provincial Lotteries (http://www.naspl.org), we construct dummy variables for lotteries in operation each year that are earmarked for elementary and secondary education. Evans and Zhang (2007) estimated that lottery profits have a significant positive effect on per pupil education spending and that the effect is somewhat larger (though still less than dollar-for-dollar) where revenues are earmarked. Miller and Pierce (1997) likewise found a significant positive effect from earmarked lottery revenues. Alm, Buschman, and Sjoquist (2007) found a significant positive effect from an earmarked lottery on state per student revenues along with a partially offsetting negative effect on local revenues, but no effect from a non-earmarked lottery at either level. Consequently, we expect that the presence of an earmarked lottery will increase the state share. 
We also ran regressions with controls for court-ordered and legislative-mandated reforms of school funding programs. Whether initiated because of a court order or legislative action, school finance reforms have been shown to affect education spending (Bahl, Sjoquist, and Williams 1990; Silva and Sonstelie1995; Evans, Murray, and Schwab 1997; Manwaring and Sheffrin 1997; Murray, Evans, and Schwab 1998; Baicker and Gordon 2006; Downes and Shah 2006; Downes 2007). We test two separate dummy variables based on Downs and Shah (2006) for court-ordered and legislated school finance reforms.

\section{EMPIRICAL RESULTS}

Tables 2 and 3 present some forty-eight state regression results for a variety of single years and five-year spans, incorporating the ANES ("Most Faith In") survey variable and the ACIR ("Least For Your Money") survey variable, respectively; since these variables are available for different years, we report regressions for different years in the two tables. The dependent variable in each model is the state share of state plus local $\mathrm{K}-12$ revenue in the single year or averaged over a five-year span, chosen on basis of the dates of these explanatory variables. All of these regressions include real per capita income and real per capita state spending net of K-12 education spending (both in logs), while the state share of non-education spending and the average district size are added beginning in the third column of each table. Each is measured as of the period falling prior to the school year(s) of the dependent variable. The final two columns of each table add the respective survey variables.

Table 2 about here

Table 3 about here 
As discussed earlier, we also tried specifications with a host of other variables as controls, including economic, demographic, and legal variables. However, likely because of the small numbers of observations in the cross-section regressions, most of these variables proved insignificant. Adding them to the specifications in Tables 2 and 3, while sometimes marginally increasing the overall R-squared, generally reduced the adjusted R-squared significantly, indicating a loss of precision in the estimates. Even so, when we did include these other control variables, our results for the "trust" variables were not qualitatively different. Accordingly, the results when these control variables are included and are found to be insignificant are typically not reported in the tables. ${ }^{8}$ Further, we estimated various models with the entire panel dataset (forty-eight states, seventeen years), using the full set of economic, demographic, and legal variables together with our indirect measures of trust (i.e., per capita state spending net of K-12 education, state spending net of K-12 education as a share of total state plus local spending net of K-12 education); note that our direct measures of trust are not available for all years of the panel. These panel regressions are discussed briefly later.

Focusing first on the cross-sections and our direct measures of "trust", the results in Tables 2 and 3 are fairly consistent across the different estimation periods and the different direct measures. The coefficient estimates for the income variable range from -0.62 to -1.0 and are always significant at 1 percent, indicating that a 1 percent higher per capita real income implies a 0.62 to 1.0 percentage point lower state share of education spending. These results suggest that higher average income levels are associated with a preference for local, rather than state, funding of education.

\footnotetext{
${ }^{8}$ For example, our property tax constraints dummy variable is statistically insignificant, with p-values of around 0.5 to over 0.9, when added alone to the base regressions and when added in combination with other variables.
} 
State non-education spending also has a fairly consistent impact, with positive estimates for all periods, but with high p-values in some of the more parsimonious models of Tables 2 and 3. In the regressions including the survey (the final two columns of each table), the coefficient estimates on per capita state non-education spending are all significant at the 1 percent or 5 percent levels. The estimates suggest that 1 percent higher per capita state non-education spending is associated with a 0.34 to 0.42 percentage point higher state share of education spending.

Coefficient estimates on the state share of non-education spending are negative, but are generally not significant. The coefficient estimates range from -0.25 to as large as -0.51 , but are only significant at the 10 percent level or better in two of the eight models where this variable is included. This result suggests that while higher spending states, outside of education, appear to tend toward greater centralization in education funding, preferences for centralization may differ depending on the governmental function at issue. Put differently, greater centralization in one area does not necessarily imply the same in another area.

Another factor that might be related to the state share is the average district size. This may reflect in part regional differences, since school districts tend to be larger in the South. ${ }^{9}$ In addition, however, smaller school districts might reflect stronger and more historic preferences for decentralization. The estimated coefficients on this variable were positive, which is consistent with the expectation that smaller school districts would be associated with more decentralized funding. However, the coefficients were statistically significant in only three regressions of the eight in Tables 2 and 3 where this variable was included (and the p-value was

\footnotetext{
${ }^{9}$ Note that we also included in some specifications regional dummy variables for more direct measures of "region". These dummy variables were never significant, and these results are not presented.
} 
0.105 on a fourth regression). Including this variable did not affect the coefficient estimates on the "trust" variables or on the control variables.

As for the "trust" variables themselves, Table 2 includes the 1996 ANES survey variable. We tried different measures drawn from both the positive "Most Faith In" and the negative "Least Faith In" questions, where each was a ratio of the respondents' choices (e.g., local-to-state or state-to-federal). The measure that produced the most significant results was the local-to-state ratio from the "Most Faith In" survey question. Adding the survey variable reduced the sample size to only twenty-three states because we only included states with at least twenty-five survey responses. Reducing the threshold below that level includes more states, but at the cost of greater measurement error in this attitude variable, while increasing the threshold makes the sample size exceedingly small. For the 1997 and the 1997-2001 models, coefficient estimates for the survey variable are negative at -0.10 and -0.12 , respectively, as one would expect; greater faith in local government versus state government seems consistent with a lower state share of education spending. The p-values for the attitude variable in the 1996 and 1997-2001 models are 0.14 and 0.06 , respectively.

Table 3 contains results for the ACIR survey variable of trust, derived from the combined results of surveys taken in $1989,1990,1992$, and 1994. The variable is the ratio of respondents choosing state government to those choosing local government as providing the "Least For Your Money", so as with the ANES variable a higher value indicates a more positive attitude toward local government compared to state government. Also as with the ANES variable, coefficient estimates are negative, as expected. However, in this case the estimates are not statistically different from zero, with p-values of 0.41 in the 1995 model and 0.66 in the 1995-1999 model. 
Again, it is possible that centralization and attitudes toward local government are driven by attitudes toward the property tax. When we included the dummy variable for property tax limitations in the various regressions, the estimated coefficient was positive, as expected, but with standard errors that were more than twice the value of the coefficient estimate. The coefficient estimates on the "trust" variables and on the other control variables were unaffected by inclusion of the property tax limitations variable. Other control variables tested (e.g., the school finance reform and lottery dummies, the demographic variables) produced estimates that were also not significant and that reduced the precision of the models.

We also estimated various models with the full panel (forty-eight states over seventeen years), using our indirect measures of preferences for centralization (per capita state spending net of K-12 education, the state share of non-education spending, and average district size), and attitudes toward property taxes. These full panel regressions allowed us to verify the results from the cross-section regressions for the indirect measures while controlling for the full range of economic, demographic, and legal variables discussed earlier. Inclusion of all these controls was not possible in the cross-section regressions because of the small numbers of observations.

Table 4 presents the panel regression results. The models presented are a pooled OLS estimation followed by three panel-corrected standard errors (PCSE) models. ${ }^{10}$ The first PCSE model corrects for cross-sectional dependence and group-wise heteroskedacticity; the second adds a correction for autocorrelation; and the third adds fixed year effects.

\footnotetext{
${ }^{10}$ In estimating the panel specifications, we tested for cross-sectional correlation of the errors and for group-wise heteroskedasticity. The results indicate that these problems are present and suggest using a panel-corrected standard errors model (PCSE), which produces standard error estimates that are robust to cross-sectional dependence and group-wise heteroskedasticity. In addition, the results indicate the presence of autocorrelation in the data. Our panel results are based on the PCSE estimations that correct for all of these issues. A state fixed effects model is not presented because our interest is in understanding cross-sectional differences across states and a fixed effects model tend to would mask those differences in favor of within-state variation over time.
} 


\section{Table 4 about here}

The panel results indicate that per capita state spending net of K-12 education has a marginally significant positive impact on the state share, consistent with the results in Tables 2 and 3, but with smaller coefficient estimates when the correction for autocorrelation is included. The other indirect measure of trust (or the state share of non-education spending) has an inconsistent and statistically insignificant impact on the state share of $\mathrm{K}-12$ spending in panel regressions, a result that is also similar to those from the cross-section regressions. Average district size, on the other hand, showed statistically significant (at the 1 percent level) positive effects on the state share of K-12 spending, with coefficient estimates similar in magnitude to those from the cross-section models. As expected, after controlling for the total number of students, states with larger districts (in terms of numbers of students) tend to rely more heavily on centralized funding.

Coefficient estimates on per capita income are also similar to those in the cross-section regressions; the estimates are negative and always significant at the 1 percent level, although of slightly smaller magnitude. As for other control variables, the lottery and school funding reform dummies and the ratio of year-end state fiscal balances to total expenditures all have significant positive estimates, while estimates on the demographic controls (other than racial uniformity) are not significant in the models correcting for autocorrelation. The coefficient estimates on racial uniformity are consistently negative, but only marginally significant in one equation, while the citizen and government ideology measures are generally statistically insignificant in the models correcting for autocorrelation; in any event, these estimates are quite small and thus economically insignificant. Finally, the share of homes that are owner-occupied shows a 
significant positive effect on the state share of education funding, suggesting that homeowners tend to prefer relatively more reliance on state than local funding sources. Higher real housing costs do not appear to have a material effect on the state share.

\section{CONCLUSIONS}

What is the appropriate role of state versus local governments in funding K-12 public education? Put differently, what are the determinants of the fiscal decentralization of state support for K-12 education? In addition to economic, demographic, and legal variables that have often been used in studies of fiscal centralization, we explore factors that measure citizen "trust" in the state versus local governments. We measure this trust in several ways, using both direct and indirect measures of trust, and we include these measures as explanatory factors in the determinants of the state support for K-12 education. These empirical results are generally supportive of the hypothesis that greater citizen trust in local governments leads to more reliance on local governments in education spending; that is, in states where citizens express relatively more faith in local governments versus state governments, the state share of K-12 funding is lower. Put differently, when citizens have greater confidence in state (versus local) government in making appropriate decisions, the actual role of state governments tends to reflect this attitude via a larger share of state support for K-12 education.

Of course, there are many ways by which state governments may be involved in the provision of local education, ways that go well beyond simply greater state support for education. In part because the translation of citizen trust into actual government spending commitments may be somewhat loose, our estimation results are sometimes imprecise. There may also be a question of causality: does greater citizen trust in (say) state government relative to 
local government cause a larger state role, or do citizens demand a larger state role because they have a prior history of effective state involvement in local education? Our estimation results are unable to address the issue of causality, although we do not think our measures of trust are likely to be affected by such endogeneity concerns. Even so, we believe that our direct measures of citizen trust provide important, if suggestive, evidence about the potential role of a factor that has received little previous attention.

We also consider more indirect measures of citizen trust, including the state share of state plus local non-education expenditures and non-education spending per capita, serving as separate measures of revealed preference for fiscal centralization. We find, inconsistent with expectations, that a larger state share of non-education expenditures is weakly associated, in cross-section regressions, with a smaller state share of K-12 funding, while we find, consistent with expectations, that the coefficients on non-education expenditures per capita are positive and generally statistically significant. Thus, state governments with larger non-education spending are associated with greater state share of education funding. Finally, the average size of a state's school districts, all else held constant, is perhaps reflective of preferences for centralization and is also positively related to the state share of school funding.

Overall, our results suggest that, while the state share of state and local K-12 funding depends on economic and demographic variables, measures of citizen's attitudes toward, or trust for, local versus state government are also important factors in predicting the state share of funding. These trust factors have not typically been considered in previous studies of decentralization broadly or education specifically, but our results suggest that measures of trust or faith in state versus local government may help in explaining the relative reliance on each in the provision of K-12 education. 


\section{REFERENCES}

Alesina, Alberto and Enrico Spolaore. 1997. On the number and size of nations. The Quarterly Journal of Economics 112 (4): 1027-1056.

Alm, James, Robert D. Buschman, and David L. Sjoquist. 2007. Fiscal problems and education finance. State Tax Notes 44 (9): 637-654.

Alvarez, R. Michael and John Brehm. 2002. Hard Choices, Easy Answers: Values, Information, and American Public Opinion. Princeton, NJ: Princeton University Press.

Bahl, Roy, David L. Sjoquist, and W. Loren Williams. 1990. School finance reform and its impact on property taxes. Proceedings of the Eighty-Third Annual Congress of the National Tax Association-Tax Institute of America. Columbus, OH: National Tax Association, 163-171.

Baicker, Katherine and Nora Gordon. 2006. The effect of state education finance reform on total local resources. Journal of Public Economics 90 (6): 1519-1535.

Becker, Gary S. 1983. A theory of competition among pressure groups for political influence. The Quarterly Journal of Economics 98 (3): 371-400.

Bergstrom, Theodore C. and Robert P. Goodman. 1993. Private demand for public goods. The American Economic Review 6 (2): 280-296.

Berry, William D., Evan J. Ringquist, Richard C. Fording, and Russell L. Hanson. 1998. Measuring citizen and government ideology in the American states, 1960-93. American Journal of Political Science 42 (1): 327-348.

Borcherding, Thomas E. and Robert T. Deacon. 1972. The demand for the services of nonfederal governments. The American Economic Review 62 (4): 891-906.

Cantril, Albert H. and Susan Davis Cantril. 1999. Reading Mixed Signals: Ambivalence in American Public Opinion about Government. Washington, D.C.: Woodrow Wilson Center Press.

Dahl, Robert A. 1989. Democracy and its Critics. New Haven, CN: Yale University Press.

deBartolome, Charles. 1997. What determines state aid to school districts? A positive model of foundation aid as redistribution. Journal of Policy Analysis and Management 16 (1): 32-47.

Dincer, Oguzhan. 2010. Fiscal decentralization and trust. Public Finance Review 38 (2): 155178.

Downes, Thomas A. 2007. Do non-school resources substitute for school resources? A review of the evidence. Tufts University Working Paper. Medford, MA. 
Downes, Thomas A. and Mona P. Shah. 2006. The effect of school finance reforms on the level and growth of per-pupil expenditures. Peabody Journal of Education 81 (3): 1-38.

Epple, Dennis and Thomas Nechyba. 2004. Fiscal decentralization. In Handbook of Regional and Urban Economics, Volume 4: Cities and Geography, J. Vernon Henderson and JacquesFrancois Thisse, eds. Boston, MA: Elsevier North-Holland, 2423-2480.

Erikson, Robert S., Michael B. MacKuen, and James A. Stimson. 2002. The Macro Polity. Cambridge, MA: Cambridge University Press.

Evans, William N., Sheila Murray, and Robert M. Schwab. 1997. Schoolhouses, courthouses, and statehouses after Serrano. Journal of Policy Analysis and Management 16 (1): 10-31.

Evans, William N. and Ping Zhang. 2007. The impact of earmarked lottery revenue on K-12 educational expenditures. Education Finance and Policy 2 (1): 40-73.

Giertz, J. Fred. 1976. Decentralization at the state and local level: An empirical analysis. National Tax Journal 29 (2): 201-209.

Hatfield, John William and Gerald Padro i Miquel. 2008. A political economy theory of partial decentralization. NBER Working Paper 14628. Cambridge, MA: National Bureau of Economic Research.

Hoxby, Caroline M. 2001. All school finance equalizations are not created equal. The Quarterly Journal of Economics 116 (4): 1189-1231.

Hoyt, William H., Paul A. Coomes, and Amelia M. Biehl. 2008. Tax limits, houses, and schools: Seemingly unrelated and offsetting effects. IFIR Working Paper No. 2009-03. Lexington, KY: Institute for Federalism \& Intergovernmental Relations.

Jametti, Mario and Marcelin Joanis. 2009. The political economy of fiscal decentralization: Evidence from the Canadian Federation. University of Quebec Working Paper. Quebec, Canada.

Joanis, Marcelin. 2009. Intertwined federalism: Accountability problems under partial decentralization. Center for Interuniversity Research and Analysis on Organizations (CIRANO) Working Paper 2009-s39. Montreal, Canada.

Letelier, Leonardo S. 2005. Explaining fiscal decentralization. Public Finance Review 33 (2): 155-183.

Manwaring, Robert L. and Steven M. Sheffrin. 1997. Litigation, school finance reform, and aggregate education spending. International Tax and Public Finance 4 (1): 107-127.

Miller, Donald and Patrick Pierce. 1997. Lotteries for education: Windfall or hoax? State and Local Government Review 29 (1): 34-42. 
Murray, Sheila, William N. Evans, and Robert M. Schwab. 1998. Education finance reform and the distribution of education resources. The American Economic Review 88 (3): 789-812.

Oates, Wallace E. 1972. Fiscal Federalism. New York, NY: Harcourt Brace Jovanovich, Inc.

Panizza, Ugo. 1999. On the determinants of fiscal centralization: Theory and evidence. Journal of Public Economics 74 (1): 97-139.

Schneider, Saundra K., William G. Jacoby, and Daniel C. Lewis. 2011. Public opinion toward intergovernmental policy responsibilities. Publius - The Journal of Federalism 4 (1): 1-30.

Silva, Fabio and Jon Sonstelie. 1995. Did Serrano cause a decline in school spending? National Tax Journal 48 (2): 199-215.

Stimson, James. 2004. Tides of Consent: How Public Opinion Shapes American Politics. Cambridge, UK: Cambridge University Press.

Strumpf, Koleman S. and Felix Oberholzer-Gee. 2002. Endogenous policy decentralization: Testing the central tenet of economic federalism. The Journal of Political Economy 110 (1): 158.

Thomas, Mary Kathleen. 2000. The State Share of Revenue for Public Education: Measuring its Magnitude and Effect on Total Per Pupil Spending in Primary and Secondary School Districts. Ph.D. dissertation, Georgia State University. Atlanta, GA.

Wallis, John Joseph and Wallace E. Oates. 1988. Decentralization in the public sector: An empirical study of state and local government. In Fiscal Federalism: Quantitative Studies, Harvey S. Rosen, ed. Chicago, IL: The University of Chicago Press, 5-28.

Wlezien, Christopher and Stuart N. Soroka. 2011. Federalism and public responsiveness to policy. Publius - The Journal of Federalism 4 (1): 31-52. 
Table 1: State Share of State plus Local K-12 Revenue

\begin{tabular}{|c|c|c|c|}
\hline State & State Share (percent) & State & State Share (percent) \\
\hline Alabama & 67.1 & Montana & 56.3 \\
\hline Alaska & 71.7 & Nebraska & 37.3 \\
\hline Arizona & 56.5 & Nevada & 29.0 \\
\hline Arkansas & 66.6 & New Hampshire & 42.4 \\
\hline California & 67.2 & New Jersey & 45.3 \\
\hline Colorado & 48.0 & New Mexico & 84.9 \\
\hline Connecticut & 41.1 & New York & 46.1 \\
\hline Delaware & 69.8 & North Carolina & 72.0 \\
\hline Florida & 45.6 & North Dakota & 45.5 \\
\hline Georgia & 50.6 & Ohio & 49.0 \\
\hline Hawaii & 99.0 & Oklahoma & 65.1 \\
\hline Idaho & 64.3 & Oregon & 57.6 \\
\hline Illinois & 33.1 & Pennsylvania & 39.3 \\
\hline Indiana & 54.3 & Rhode Island & 45.0 \\
\hline Iowa & 51.5 & South Carolina & 52.4 \\
\hline Kansas & 61.6 & South Dakota & 41.0 \\
\hline Kentucky & 66.3 & Tennessee & 51.3 \\
\hline Louisiana & 53.8 & Texas & 39.4 \\
\hline Maine & 48.0 & Utah & 62.5 \\
\hline Maryland & 43.1 & Vermont & 94.2 \\
\hline Massachusetts & 50.6 & Virginia & 43.4 \\
\hline Michigan & 65.9 & Washington & 69.2 \\
\hline Minnesota & 78.8 & West Virginia & 68.7 \\
\hline Mississippi & 66.5 & Wisconsin & 57.1 \\
\hline Missouri & 38.4 & Wyoming & 49.9 \\
\hline United States & 52.5 & & \\
\hline
\end{tabular}

Source: U.S. Department of Education, National Center for Education Statistics, Digest of Education Statistics: 2008, Table 172, available online at:http://nces.ed.gov/programs/digest/d08/tables/dt08_172.asp?referrer=list (accessed 2/2/2010) 


\section{Table 2: Regressions with ANES Survey Variable - "Most Faith In"}

Dependent Variable: State Share of State plus Local Elementary and Secondary Education Revenues

\begin{tabular}{|c|c|c|c|c|c|c|}
\hline School Year(s) Ending & 1997 & $1997-2001$ & 1997 & $1997-2001$ & 1997 & $1997-2001$ \\
\hline Income Per Capita (log) & $\begin{array}{l}-0.6850 * * * \\
(0.147)\end{array}$ & $\begin{array}{l}-0.6200 * * * \\
(0.121)\end{array}$ & $\begin{array}{l}-0.9077 * * * \\
(0.150)\end{array}$ & $\begin{array}{l}-0.7592 * * * \\
(0.132)\end{array}$ & $\begin{array}{l}-1.0017 * * * \\
(0.305)\end{array}$ & $\begin{array}{l}-0.9050 * * * \\
(0.263)\end{array}$ \\
\hline $\begin{array}{l}\text { State Spending Per Capita Net } \\
\text { of Education Spending }(\log )\end{array}$ & $\begin{array}{r}0.1383 \\
(0.105)\end{array}$ & $\begin{array}{l}0.1775 * * \\
(0.086)\end{array}$ & $\begin{array}{l}0.3420 * * * \\
(0.117)\end{array}$ & $\begin{array}{l}0.3059 * * * \\
(0.103)\end{array}$ & $\begin{array}{l}0.4159 * * \\
(0.157)\end{array}$ & $\begin{array}{l}0.4207 * * * \\
(0.136)\end{array}$ \\
\hline $\begin{array}{l}\text { State Share of Non-Education } \\
\text { Spending }\end{array}$ & & & $\begin{array}{l}-0.4529 * * \\
(0.219)\end{array}$ & $\begin{array}{r}-0.2971 \\
(0.193)\end{array}$ & $\begin{array}{r}-0.5000 \\
(0.355)\end{array}$ & $\begin{array}{r}-0.4897 \\
(0.306)\end{array}$ \\
\hline Average District Size (log) & & & $\begin{array}{l}0.0447 * * \\
(0.017)\end{array}$ & $\begin{array}{r}0.0252 \\
(0.015)\end{array}$ & $\begin{array}{r}0.0248 \\
(0.029)\end{array}$ & $\begin{array}{r}0.0206 \\
(0.025)\end{array}$ \\
\hline ANES "Most Faith In" 1 & & & & & $\begin{array}{r}-0.1009 \\
(0.065)\end{array}$ & $\begin{array}{c}-0.1152 * \\
(0.056)\end{array}$ \\
\hline Constant & $\begin{array}{l}6.3753 * * * \\
(1.397)\end{array}$ & $\begin{array}{l}5.4250 * * * \\
(1.149)\end{array}$ & $\begin{array}{l}6.9425 * * * \\
(1.281)\end{array}$ & $\begin{array}{l}5.8019 * * * \\
(1.129) \\
\end{array}$ & $\begin{array}{l}7.6140 * * * \\
(2.284)\end{array}$ & $\begin{array}{l}6.6441 * * * \\
(1.969)\end{array}$ \\
\hline Observations & 48 & 48 & 48 & 48 & 23 & 23 \\
\hline F-test (p-value) & 0.0001 & 0.0000 & 0.0000 & 0.0000 & 0.0227 & 0.0101 \\
\hline R-squared & 0.3273 & 0.3679 & 0.4900 & 0.4498 & 0.5092 & 0.5599 \\
\hline Adjusted R-squared & 0.2974 & 0.3398 & 0.4425 & 0.3986 & 0.3649 & 0.4304 \\
\hline
\end{tabular}

Standard errors are in parentheses.

$* * *$ indicates significance at $1 \%$ level, $* *$ at $5 \%, *$ at $10 \%$.

${ }^{1}$ ANES "Most Faith In" is the ratio of survey respondents indicating they have the "most faith in" local government to those indicating state government. States are included only where survey respondents numbered 25 or more. The survey year is 1996. 
Table 3: Regressions with ACIR Survey Variable - "Least For Your Money"

Dependent Variable: State Share of State plus Local Elementary and Secondary Education Revenues

\begin{tabular}{|c|c|c|c|c|c|c|}
\hline School Year(s) Ending & 1995 & 1995-1999 & 1995 & 1995-1999 & 1995 & 1995-1999 \\
\hline Income Per Capita (log) & $\begin{array}{l}-0.6616 * * * \\
(0.162)\end{array}$ & $\begin{array}{l}-0.6568 * * * \\
(0.151)\end{array}$ & $\begin{array}{l}-0.8531 * * * \\
(0.175)\end{array}$ & $\begin{array}{l}-0.8528 * * * \\
(0.163)\end{array}$ & $\begin{array}{l}-0.8989 * * * \\
(0.190)\end{array}$ & $\begin{array}{l}-0.9388 * * * \\
(0.179)\end{array}$ \\
\hline $\begin{array}{l}\text { State Spending Per Capita Net } \\
\text { of Education Spending (log) }\end{array}$ & $\begin{array}{r}0.0958 \\
(0.108)\end{array}$ & $\begin{array}{r}0.1000 \\
(0.087)\end{array}$ & $\begin{array}{l}0.2462 * \\
(0.127)\end{array}$ & $\begin{array}{l}0.2567 * * \\
(0.118)\end{array}$ & $\begin{array}{l}0.3392 * * \\
(0.146)\end{array}$ & $\begin{array}{l}0.3454 * * \\
(0.138)\end{array}$ \\
\hline $\begin{array}{l}\text { State Share of Non-Education } \\
\text { Spending }\end{array}$ & & & $\begin{array}{r}-0.2511 \\
(0.235)\end{array}$ & $\begin{array}{r}-0.2934 \\
(0.219)\end{array}$ & $\begin{array}{r}-0.4419 \\
(0.281)\end{array}$ & $\begin{array}{c}-0.5072 * \\
(0.266)\end{array}$ \\
\hline Average District Size (log) & & & $\begin{array}{c}0.0486 * * \\
(0.019)\end{array}$ & $\begin{array}{c}0.0431 * * \\
(0.018)\end{array}$ & $\begin{array}{r}0.0153 \\
(0.027)\end{array}$ & $\begin{array}{r}0.0128 \\
(0.025)\end{array}$ \\
\hline ACIR "Least For Your Money" 1 & & & & & $\begin{array}{r}-0.0317 \\
(0.038)\end{array}$ & $\begin{array}{r}-0.0159 \\
(0.036)\end{array}$ \\
\hline Constant & $\begin{array}{l}6.4406 * * * \\
(1.494)\end{array}$ & $\begin{array}{l}0.6372 * * * \\
(1.393)\end{array}$ & $\begin{array}{l}6.9629 * * * \\
(1.450)\end{array}$ & $\begin{array}{l}6.9591 * * * \\
(1.348)\end{array}$ & $\begin{array}{l}7.1392 * * * \\
(1.724)\end{array}$ & $\begin{array}{l}7.5435 * * * \\
(1.628)\end{array}$ \\
\hline Observations & 48 & 48 & 48 & 48 & 36 & 36 \\
\hline F-test (p-value) & 0.0006 & 0.0003 & 0.0002 & 0.0001 & 0.0007 & 0.0003 \\
\hline R-squared & 0.2787 & 0.3035 & 0.4020 & 0.4258 & 0.4927 & 0.5205 \\
\hline Adjusted R-squared & 0.2466 & 0.2725 & 0.3463 & 0.3723 & 0.4082 & 0.4406 \\
\hline
\end{tabular}

Standard errors are in parentheses.

$* * *$ indicates significance at $1 \%$ level, ** at $5 \%, *$ at $10 \%$.

${ }^{1}$ ACIR "Least For Your Money" is the ratio of survey respondents choosing the state government to those choosing local government as giving the "Least For Your Money." States are included only where survey respondents numbered 25 or more. Survey years are 1989, 1990, 1992, and 1994. 


\section{Table 4: Panel Regressions ${ }^{1}$}

Dependent Variable: State Share of State plus Local Elementary and Secondary Education Revenues



Standard errors are in parentheses. $* * *$ indicates significance at the $1 \%$ level, $* *$ at $5 \%$, and $*$ at $10 \%$.

${ }^{1}$ PCSE model 1 corrects for cross-sectional dependence and groupwise heteroskedasticity; PCSE 2 also corrects for autocorrelation; and PCSE 3 adds y ear fixed effects. 


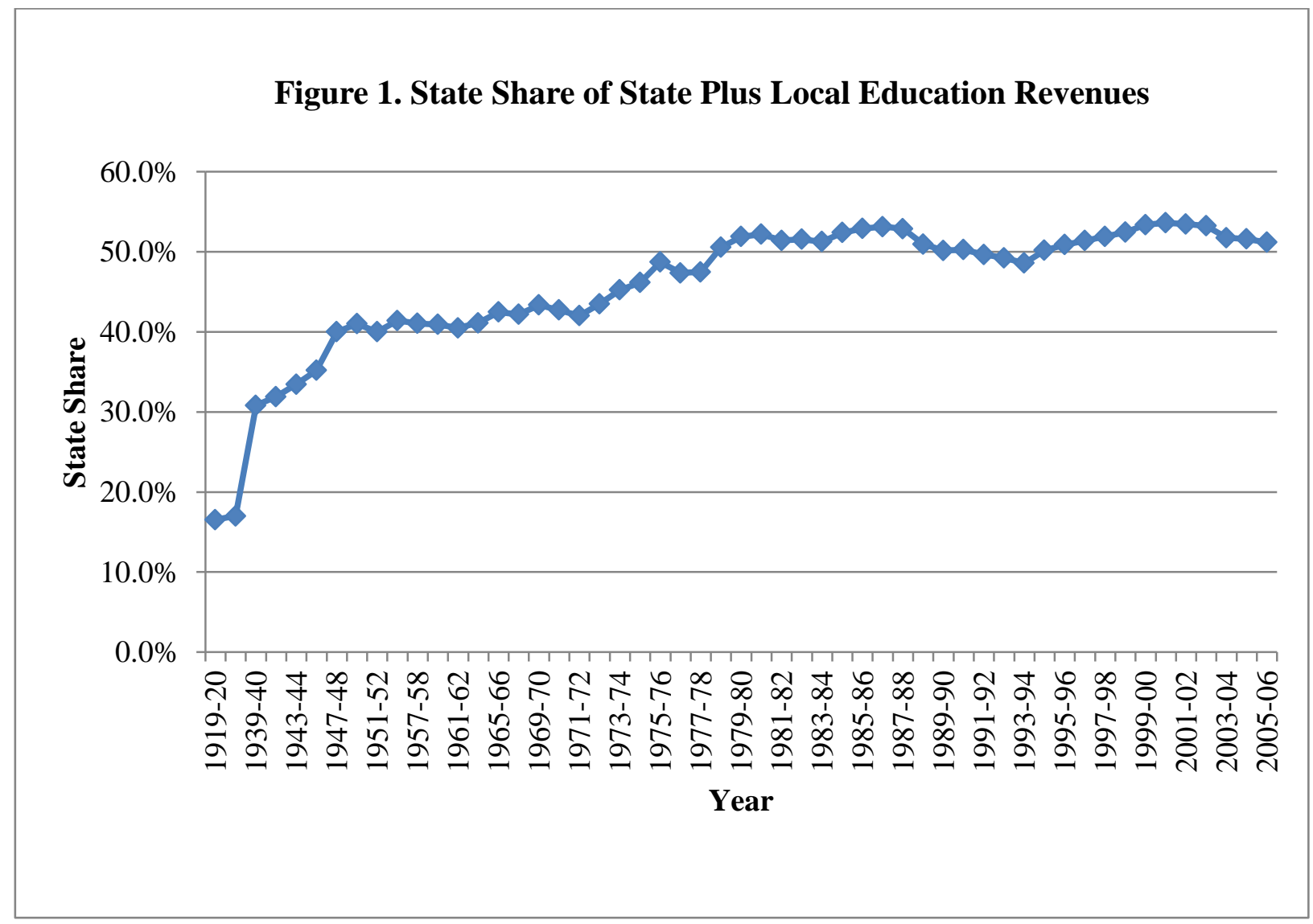


Figure 2. State Share of State plus Local Education Revenues

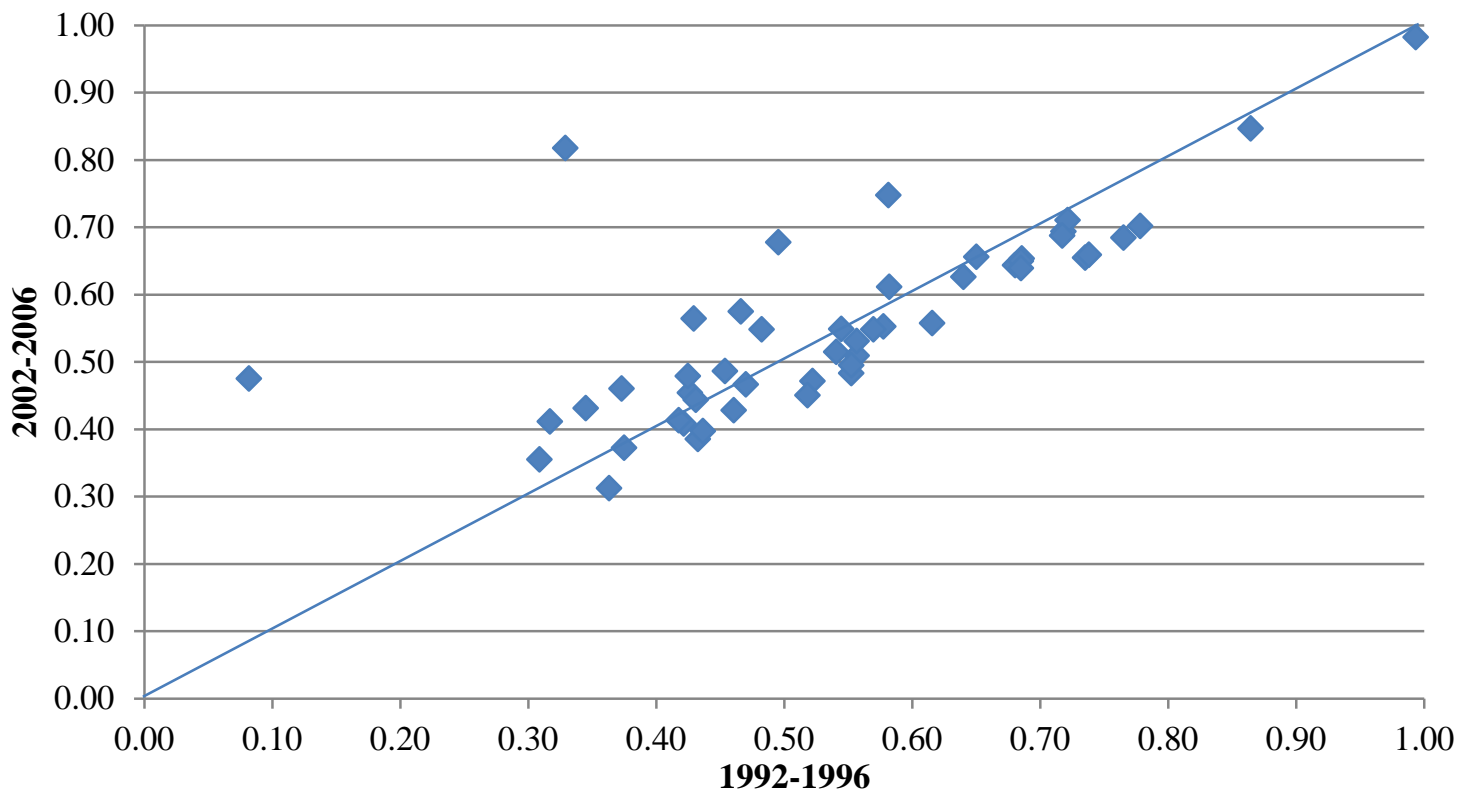

